\title{
Effect of Non - Genetic Factors on Production Traits in Deoni Cows
}

\author{
S.S. Bhutkar ${ }^{1}$., B. M. Thombre ${ }^{2}$ and D.V. Bainwad ${ }^{3}$ \\ Department of Animal Husbandry and Dairy Science, \\ College of Agriculture, Vasantrao Naik Marathwada Krishi Vidyapeeth, Parbhani 431402 (MS) India
}

\begin{abstract}
The research was conducted to evaluate the effect of non - genetic factors on production traits in Deoni cattle. Data representing 114 Deoni cows from 211 total records of lactation over a 30 years period were analysed to determine the effect of age at first calving, season of calving and period of calving on production traits. The overall least squares means of lactation milk yield, peak milk yield, days to reach peak milk yield, lactation period and dry period were $358.31 \pm 27.18,3.14 \pm 0.18,44.81 \pm 2.52,213.90 \pm 13.74$ and $211.93 \pm$ 26.23. The age at first calving were significant effect on lactation milk yield, peak milk yield and days to reach peak milk yield, whereas non significantly affected on lactation period and dry period. All sources of variation for season of calving on production traits were non significant. The period of calving had significant effect on lactation milk yield, peak milk yield and dry period, whereas non significantly affected on days to reach peak milk yield and lactation period.
\end{abstract}

Keyword: CCBP, Deoni, Genetic factors, Production, Traits,

\section{Introduction}

In India, there are about 37 breeds of cattle among this cattle breeds Deoni and Red Kandhari cattle have gifted to Marathwada region. Deoni is one of the important dual purpose cattle breeds of Marathwada native to adjoining areas of Maharashtra, Andhra Pradesh and Karnataka state. The migration of Gir breed of cattle to Marathwada region and the consequent admixture with Dangi and local cattle. The home tract of Deoni breed is Udgir, Ahmedpur, Nilanga and Ausa tehsils of Latur district of Maharashtra and adjoining areas of Andhra Pradesh, Bidar and Gulbarga districts of Karnataka state. Deoni bullocks are suitable for heavy cultivation and carting works (Suryawamshi et al. 2000). The population of Deoni breed of cattle is dwindling and information on the productive traits of these cattle is scanty. Hence the present investigation was taken to study productive traits of Deoni cattle.

\section{Materials And Methods}

\subsection{Study area}

This study was conducted at Cattle Cross Breeding Project (CCBP) of Vasantrao Naik Marathwada Krishi Vidyapeeth, Parbhani. The CCBP is situated between $17^{\circ} 35^{\prime} \mathrm{N}$ and $20^{\circ} 40^{\prime} \mathrm{N}$ latitude and between $70^{\circ}$ $40^{\circ} \mathrm{N}$ and $78^{\circ} 15^{\prime} \mathrm{E}$ longitude. The mean daily maximum temperature varies from $29.1^{\circ} \mathrm{C}$ in December to $42.5^{\circ}$ $\mathrm{C}$ in May. The mean daily minimum temperature varies from $6.9^{0} \mathrm{C}$ in December to $25.4^{0} \mathrm{C}$ in May. The relative humidity ranges from 11 to 90 per cent. Normally the summer becomes hot and general dryness persists though out the year except during south-west monsoon. The region is essentially a subtropical one and it comes under assured rainfall zones with an average rainfall of $900 \mathrm{~mm}$ spread in about 70 rainy days mostly received from June to September.

\subsection{Management of animals}

The management and feeding practices followed on CCBP research farm is uniform. Deoni receive their ration according to the feeding schedule. After commencement of rainy season within a month grazing is available and grazing practices are followed from mid of July to end of January in addition to grazing regular feeding of dry and green is practiced. At the time of morning and evening milking concentrates are allowed to each individual cow in accordance of their requirement for maintenance plus production. Dry roughages of sorghum and the green as per availability (Green maize, Lucerne, Green Jowar, Natural grasses) are fed to them. Good housing facilities exist at the farm. Enough health cover is provided to protect the animals from epidemics and causal incidences of ill- health and eventualities.

\subsection{Sources and nature of data}

Data representing 114 Deoni cows from CCBP with 211 total records of lactation over a 30 years period ( 1981 to 2010 ) were collected and organized to study the effect of age at first calving, season of calving and period of calving on production traits. The complete years was divided into 4 seasons and 6 periods having 
5 years each. Five levels of age at first calving (AFC) were coded as $A_{1}<1200$ days to $A_{6}<1600$ days with class interval 150 days. The four seasons namely winter ( December to February), summer ( March to May), monsoon ( June to September) and post monsoon (October to November) were codeded as $S_{1}, S_{2}, S_{3}$ and $S_{4}$. Each cow having at least theree offsprings was considered in this study.

\subsection{Statistical analysis}

Data were analysed by linear model (SAS, 2002). When the analysis of variance indicated the existance of significant within class, Duncan Multiple Range Test (DMRT) by Kramar (1957) were emplyoed to test and locate means that are significantly differed from the rest.

The following statistical model was employed to analyse the data.

$Y_{i j k}=\mu+S_{i}+P_{j}+e_{i j k}$

Where,

$\mathrm{Y}_{\mathrm{ijk}}=$ is the record of a cow calved during $\mathrm{j}^{\text {th }}$ period in $\mathrm{i}^{\text {th }}$ season

$\mu=$ is the population mean common to all the observations

$\mathrm{S}_{\mathrm{i}}=$ is the effect of $\mathrm{i}^{\text {th }}$ season of calving (1..4)

$P_{j}=$ is the effect of $j^{\text {th }}$ period of calving (1..6)

$\mathrm{e}_{\mathrm{ijk}}=$ is the random error assumed to be $\mathrm{NID}\left(0, \delta^{2}, \mathrm{e}\right)$

\subsection{Lactation milk yield}

\section{Results And Discussion}

Performance of dairy animal is judged from the milk it produces during a specified period of lactation. Variation observed in lactation milk yield from lactation to lactation in the same animal. The main reason of variation attributed to the physiology of lactation is the given set of genes and their reaction with non- genetic factors. The lactation performance of dairy cattle is usually measured by total milk yield per lactation.

The least squares means and ANOVA of lactation milk yield as affected by AFC, season and period of calving are presented in Table 1 and 2, respectively. The overall LSM of LMY of Deoni cow was $358.31 \pm$ 27.18 kg. Similar results were reported by Thombre (1996), Salunkhe (2007), Mruttu (2013) in Deoni cattle.

\subsubsection{Effect of age at first calving on lactation milk yield}

The lactation milk yield was significantly $(\mathrm{P}<0.01)$ influenced by AFC. The highest LMY was observed from the cows that had AFC groups $\mathrm{A}_{1}$ followed by cows that had AFC group $\mathrm{A}_{2}$ and the lowest of all from those cows, which had AFC group $A_{5}$. Similar results were reported by Yadav and Rathi (1992) in Hariana cattle, Thombre et al.(2001) in Deoni cattle, Monalisa et al.(2010) in Sahiwal cattle and Mruttu (2013) in Deoni cattle.

\subsubsection{Effect of season of calving on lactation milk yield}

The LMY was non significantly affected by season of calving. Maximum production was occurred during monsoon season. Milk production was depressed for cows calving in summer. The variation among LMY was non significant as Deoni cattle genotype are resourceful to tolerate the seasonal changes in Maharashtra state and can flourish comfortably at CCBP farm, Parbhani. These results were in agreement with Shelke et al.(1992) in Red Kandhari, Jagtap et al.(1994) in Red Sindhi, Thombre et al.(2002), Salunkhe (2007) and Mruttu (2013) in Deoni cattle.

\subsubsection{Effect of period of calving on lactation milk yield}

The lactation milk yield was affected by period of calving $(\mathrm{P}<0.01)$. The variation in LMY observed in different periods indicates the level of management as well as environmental effects. Similar results showing significant effect of period of calving on LMY was reported by Nagadwali et al. (1996) in Sahiwal, Thombre (1996) in Deoni, Dhaware et al.(2008) in Khillar and Mruttu (2013) in Deoni cattle.

\subsection{Peak milk yield}

The least squares means and ANOVA of peak milk yield as affected by AFC, season and period of calving are presented in Table 1 and 2, respectively. The overall LSM of PMY of Deoni cow was $3.14 \pm 0.18$ $\mathrm{kg}$. The results were similar to Ramesha (2001) in Khillar cattle, Joshi et al.(2005) in Bachaur, Vechur and Ongole cattle.

\subsubsection{Effect of age at first calving on peak milk yield}

The analysis of variance indicated that effect due to age at first calving groups on PMY in Deoni cow was significant $(\mathrm{P}<0.01)$ (Table 2). $\mathrm{A}_{1}$ had significantly higher PMY than cows born in $\mathrm{A}_{5}, \mathrm{~A}_{4}, \mathrm{~A}_{2}$ and $\mathrm{A}_{3}$ 
groups. This is indicated that high AFC will ultimately affects the peak milk yield. Similar results reported by Pathak (1980) in Tharparkar and Sahiwal cattle, Yadav and Rathi (1992) in Hariana, cattle.

\subsubsection{Effect of season of calving on peak milk yield}

The statistical analysis revealed that observed differences of PMY due to season of calving were non significant. The variation among PMY was non significant indicated that irrespective of any season of calving the cows their PMY remains unchanged and does not get significantly deviated. These results were in agreement with Chauhan et al.(1976) in Sahiwal, Tharparkar and Red Sindhi cattle, Gogoi et al.(1993) in Red Sindhi cattle, Patil (1997) in Sahiwal cattle, Salunkhe (2007) in Deoni cattle.

\subsubsection{Effect of period of calving on peak milk yield}

The analysis of variance indicated that effect due to period of calving on PMY in Deoni cow was significant $(\mathrm{P}<0.05)$ (Table 2). The higher peak milk yield was observed in $\mathrm{P}_{6}$ than other periods. Similar results showing significant effect of period of calving on PMY were reported by Joshi et al. (1989) in Rathi cattle, Nanavati and Qureshi (1996) in Gir cattle, Khadda et al.(2012) in Tharparkar cattle and Kumar et al.(2012) in Sahiwal cattle.

\subsection{Days to reach peak milk yield}

Days to reach peak yield is one of the major factor which determines the lactation yield, lactation length and shape of lactation curve. The least squares means and ANOVA of days to reach peak milk yield as affected by AFC, season and period of calving are presented in Table 1 and 2, respectively. The overall LSM of DRPMY of Deoni cow was $44.81 \pm 2.52$ days. The results were close to Nanavati and Qureshi (1996) in Gir cattle and Bhadoria et al.(2002) in Gir cattle.

\subsubsection{Effect of age at first calving on days to reach peak milk yield}

The days to reach peak milk yield was significantly ( $\mathrm{P}<0.01$ ) influenced by AFC. The highest DRPMY was observed from the cows that had AFC groups $A_{1}$ followed by cows that had AFC group $A_{5}$ and the lowest of all from those cows, which had AFC group $\mathrm{A}_{2}$. Similar results reported by Balaine et al.(1970) in Hariana cattle and D'Souza et al.(1979) in Red Sindhi cattle.

\subsubsection{Effect of season of calving on days to reach peak milk yield}

The analysis of variance indicated that effect due to season of calving on DRPMY in Deoni cow was non significant. Season $S_{4}$ had significantly higher DRPMY than cows calved than $S_{2}, S_{3}$ and lowest in $S_{1}$. This has indicated that irrespective of any season of calving the cows for their DRPMY remains unchanged and do not get significantly deviated. These results were in agreement with Raheja (1982) in Hariana cattle, Nanavati and Qureshi (1996) in Gir cattle, Salunkhe (2007) in Deoni cattle and Khadda et al.(2012) in Tharparkar cattle.

\subsubsection{Effect of period of calving on days to reach peak milk yield}

The days to reach peak milk yield was non significantly affected by period of calving (Table 2). Similar results showing non significant effect of period of calving on DRPMY was reported by Tomar and Pandey (1995) in Tharparkar cattle.

\subsection{Lactation period}

The least squares means and ANOVA of lactation period as affected by AFC, season and period of calving are presented in Table 1 and 3, respectively. The overall LSM of LP of Deoni cow was $213.90 \pm 13.74$ days. The results were agreement with Dhumal et al.(1989) in Red Kandhari cattle, Joshi et al.(2005) in Ongole cattle, Dhaware et al.(2008) in Khillar cattle, and Mruttu (2013) in Deoni cattle.

\subsubsection{Effect of age at first calving on lactation period}

The lactation period was non significantly affected by age at first calving. The LP ( Days) was higher in cows born during $\mathrm{A}_{2}$ followed by $\mathrm{A}_{3}, \mathrm{~A}_{4}, \mathrm{~A}_{5}$ and lowest in $\mathrm{A}_{1}$. This has revealed that AFC not interfering with LP and therefore it provides an scope for selection of animals with low AFC with comparatively optimum LP. Similar results were reported by Balaine et al.(1970) in Hariana cattle, Umrikar et al. (1990) in Gir cattle, Gaur and Raheja (1996) in Sahiwal cattle and Salunkhe (2007) in Deoni cattle.

\subsubsection{Effect of season of calving on lactation period}

The lactation period was non significantly affected by season of calving. This indicated that Deoni genotype are efficient tolerate the seasonal changes and get comfortable. These results were in agreement with 
Latpate (1995) in Red Kandhari cattle, Patil (1997) in Sahiwal cattle, Vinoo et al.(2005) in Ongole cattle and Salunkhe (2007) in Deoni cattle.

\subsubsection{Effect of period of calving on lactation period}

The statistical analysis revealed that observed differences of LP due to period of calving were non significant. The variation among LP was non significant indicated that irrespective of any period of calving the cows their PMY remains unchanged and does not get significantly deviated. Similar results showing non significant effect of period of calving on LP was reported by Malhotra and Singh (1980) and Gupta and Tripathi (1994) in Red Sindhi cattle and Vinoo et al.(2005) in Ongole cattle.

\subsection{Dry period}

Dry period is important economic trait causing the variations in calving interval and thus indirectly affects production efficiency of cattle. The least squares means and ANOVA of dry period as affected by AFC, season and period of calving are presented in Table 1 and 3, respectively. The overall LSM of DP of Deoni cow was $211.93 \pm 26.23$ days.

\subsubsection{Effect of age at first calving on dry period}

The highest dry period was observed from cows that had AFC group $\mathrm{A}_{1}$ followed by $\mathrm{A}_{5}, \mathrm{~A}_{4}, \mathrm{~A}_{3}$ and lowest in $\mathrm{A}_{2}$. DMRT indicated that, observed differences for DP due to AFC effect were non - significant. Similar results were reported by Dubey and Singh (2005) in Sahiwal cattle, Vinoo et al.(2005) in Ongole cattle and Mruttu (2013) in Deoni cattle.

\subsubsection{Effect of season of calving on dry period}

The effect of season of calving on dry period was non significant. The LSM for DP ( Days) was higher in cows calved during $S_{2}$ followed by $S_{1}, S_{3}$ and lowest in $S_{4}$. The present results revealed that season of calving were not significantly affected DP in the herd and capable with prevailing environmental conditions and weather changes. These results were in agreement with Chawala and Mishra (1982) and Patil (1997) in Sahiwal cattle, Vinoo et al.(2005) in Ongole cattle, Nanavati and Singh (2009) in Nimari cattle and Mruttu (2013) in Deoni cattle.

\subsubsection{Effect of period of calving on dry period}

The dry period was significantly $(\mathrm{P}<0.05$ ) affected by period of calving. Similar results showing significant effect of period of calving on DP was reported by Reddy and Nagarcenkar (1990) in Sahiwal cattle, Nanavati and Singh (2009) in Nimari cattle and Mruttu (2013) in Deoni cattle.The variaiton in DP in different periods indicates the level of management as well as enviornmental effect.

Table 1. Least square means and standard error for Lactation milk yield ( LMY), Peak milk yield (PMY), Days to reach peak milk yield (DRPMY), Lactation period ( LP) and Dry period (DP) as affected by AFC groups, season of calving and period of calving in Deoni cows

\begin{tabular}{|c|c|c|c|c|c|c|c|}
\hline Source & Code & LMY(Kg) & PMY (Kg) & $\begin{array}{l}\text { DRPMY } \\
\text { (Days) }\end{array}$ & LP ( Days) & DP ( Days & \\
\hline Overall mean & $\mu$ & $358.31 \pm 27.18$ & $3.14 \pm 0.18$ & $4.81 \pm 2.52$ & $213.90 \pm 13.74$ & $\begin{array}{l}211.93 \\
26.23\end{array}$ & \pm \\
\hline \multirow[t]{9}{*}{ AFC groups } & & $405.13^{\mathrm{a}}$ & $4.13^{\mathrm{a}} \pm 0.71$ & $43.01^{\mathrm{ab}}$ & $168.74 \pm 54.58$ & 266.22 & \pm \\
\hline & \multirow{2}{*}{$\mathrm{A}_{1}$} & 10.80 & & 10.02 & & 10.42 & \\
\hline & & $370.87^{\mathrm{a}}$ & $3.03^{\mathrm{b}} \pm 0.17$ & $41.55^{\mathrm{b}} \pm 2.39$ & $227.52 \pm 13.05$ & 199.09 & \pm \\
\hline & \multirow[t]{2}{*}{$\mathrm{A}_{2}$} & 25.83 & & & & 24.93 & \\
\hline & & $359.50^{\mathrm{b}}$ & $2.97^{b} \pm 0.15$ & $42.41^{\mathrm{b}} \pm 2.14$ & $218.87 \pm 11.70$ & 211.46 & \pm \\
\hline & $\mathrm{A}_{3}$ & $\begin{array}{l}23.16 \\
39203^{\mathrm{a}}\end{array}$ & & & & 22.35 & \\
\hline & \multirow{2}{*}{$\mathrm{A}_{4}$} & $\begin{array}{l}392.03^{\circ} \\
23.01\end{array}$ & $3.19^{\circ} \pm 0.15$ & $43.99^{\circ} \pm 2.13$ & $215.70 \pm 11.62$ & $\begin{array}{l}212.02 \\
22.21\end{array}$ & \pm \\
\hline & & $340.02^{\mathrm{b}}$ & $3.23^{\mathrm{b}} \pm 0.11$ & $46.08^{a} \pm 1.62$ & $206.64 \pm 8.85$ & 213.84 & \pm \\
\hline & $\mathrm{A}_{5}$ & 17.51 & & & & 16.90 & \\
\hline \multirow{3}{*}{$\begin{array}{l}\text { Season } \\
\text { calving }\end{array}$} & & $350.60 \pm 29.64$ & $3.06 \pm 0.19$ & $43.35 \pm 2.75$ & $211.34 \pm 14.98$ & 211.16 & \pm \\
\hline & & $338.75 \pm 32.42$ & $3.14 \pm 0.21$ & $45.29 \pm 3.00$ & $216.90 \pm 16.38$ & 228.01 & \pm \\
\hline & $\begin{array}{l}\mathrm{S}_{2} \\
\mathrm{~S}_{3}\end{array}$ & $373.64 \pm 29.46$ & $3.20 \pm 0.19$ & $44.42 \pm 2.73$ & $218.00 \pm 14.89$ & $\begin{array}{l}209.80 \\
28.43\end{array}$ & \pm \\
\hline
\end{tabular}




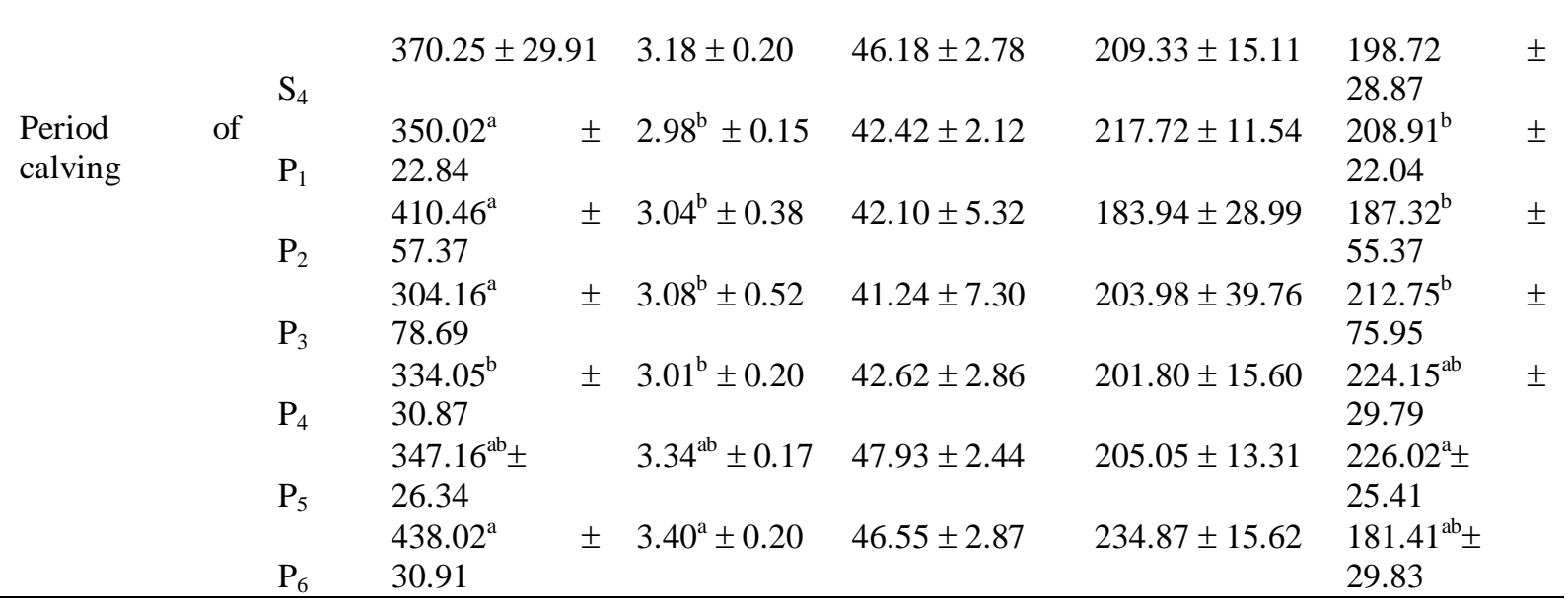

Table 2. Analysis of variance for Lactation milk yield ( LMY), Peak milk yield (PMY), Days to reach peak milk yield (DRPMY) on AFC groups, season of calving and period of calving in Deoni cows

\begin{tabular}{lllllllll}
\hline Sources & DF & LMY & \multicolumn{3}{c}{ PMY } & \multicolumn{3}{c}{ DRPMY } \\
\cline { 2 - 8 } & & MSS ('000) & $\begin{array}{l}\text { F } \\
\text { calculated }\end{array}$ & $\begin{array}{l}\text { MSlue } \\
\text { ('(000) }\end{array}$ & $\begin{array}{l}\text { F calculated } \\
\text { calue }\end{array}$ & $\begin{array}{l}\text { MSS } \\
\text { ('000) }\end{array}$ & $\begin{array}{l}\text { F calculated } \\
\text { calue }\end{array}$ \\
\hline AFC & 4 & 39210.00 & $3.55^{* *}$ & 2.07 & $4.32^{* *}$ & 389.40 & $4.19^{* * *}$ \\
Season & 3 & 11540.00 & $1.05^{\mathrm{NS}}$ & 0.23 & $0.47^{\mathrm{NS}}$ & 70.21 & $0.74^{\mathrm{NS}}$ \\
Period & 5 & 83640.00 & $7.58^{* *}$ & 1.29 & $2.70^{* *}$ & 168.60 & $1.77^{\mathrm{NS}}$ \\
Error & 198 & 11040.00 & & 0.48 & & 95.11 & \\
Total & 211 & & & & & & \\
\hline
\end{tabular}

Table 3. Analysis of variance for Lactation period (LP) and Dry period (DP) on AFC groups, season of calving

\begin{tabular}{llllll} 
& \multicolumn{5}{c}{ and period of calving in Deonicows } \\
\hline Sources & DF & LP & & DP & \\
\cline { 3 - 6 } & & MSS ('000) & F value calculated & MSS ('000) & F value calculated \\
\hline AFC & 4 & 1682.00 & $0.60^{\mathrm{NS}}$ & 8648.00 & $0.84^{\mathrm{NS}}$ \\
Season & 3 & 841.60 & $0.30^{\mathrm{NS}}$ & 5090.00 & $0.49^{\mathrm{NS}}$ \\
Period & 5 & 6074.00 & $2.15^{\mathrm{NS}}$ & 29740.00 & $2.89^{*}$ \\
Error & 198 & 2820.00 & & 10290.00 & \\
Total & 211 & & & & \\
\hline
\end{tabular}

\section{Conclusion}

This study indicates that the performance of Deoni cows for lactation milk yield, peak milk yield and lactation period is comparatively low which needs an improvement in overall management of the dairy cows. Morever, for all productional traits concerns seasonal changes had not any affects. Therefore, additional production strategies like improving enviornmental factors and managemental factors needed to improve the production performance.

\section{References}

[1]. Balaine, D. S., Gill, G. S and Acharya, R. M, Effectiveness of Components of Lactation Selecting of Milk Production in Hariana Cattle. Journal Dairy. Sci. 53, 1970, 1064-1068.

[2]. Bhadoria, H. B. S., Khan, F. H., Tomar, S. S and Yadav, M. C., Sources of Variation in Some of the Productive Traits of Gir Cows. Indian J. Anim. Sci. 72 (2), 2002, 157-158.

[3]. Chauhan, R. S., Bhatnagar, D. S. and Mishra, R. R., Effect of Parity and Season on the Peak Record and Days to Attain Peak Yield in Zebu Cattle. Indian Vet. J. 53, 1976, 1-5.

[4]. Chawala, D. S. and Mishra, R. R., Non Genetic Factors Affecting Production Traits in Sahiwal Cattle. Indian Vet. J. 59 (1), 1982 , 44-48.

[5]. D'Souza Casiein, Bhat, P. N and Mukundan, G, Genetic Studies on Some Important Economic Traits in Red Sindhi and its Crosses. Indian J. Anim. Sci. 49 (4), 1979, 247-250.

[6]. Dhaware, S. A., Deshpande. K. S., Thombre, B. M., Deshmukh, D. S and Chauhan D. S, Evaluation of Some Economic Traits in Khillar Cattle. Indian J. Anim. Res. 42(1), 2008, 60-62.

[7]. Dhumal, M. V., Sakhare, P. S and Deshpande, K. S., Factors Affecting Lactation Milk Yield and Lactation Length in Red Kandhari and Crossbred Cows. Indian J. Dairy. Sci. 42 (1) ,1989, 102-104.

[8]. Dubey, P. P and Singh, C. V., Estimates of Genetic and Phenotypic Parameters Considering First Lactation and Lifetime Performance Traits in Sahiwal and Crossbred Cattle. Indian J. Anim. Sci. 75(11) , 2005, 1289-1294.

[9]. Gaur, G. K. and Raheja, K. L, Best Linear Unbiased Estimates of Different Enviornmental Effects for Production and Reproduction Traits in Sahiwal. Indian J. Anim. Sci. 66 (6), 1996, 603-606. 
[10]. Gogoi, D. N., Goswami, R. N. and Dais, D.,First Lactation Performance of Jersey, Red Sindhi and Thier $F_{1}$ Cross Under the Farm Conditions of Assam. Indian J. Anim. Sci. 63 (5), 1993, 569-572.

[11]. Gupta, A. K and Tripathi, V. N. Effect of Parity, Season and Period on Red Sindhi Cattle. Indian J. Dairy. Sci.47 (11), 1994, 976978.

[12]. Jagtap, D. Z., Bansod, R. S. and Belhe, N. D., First Lactation Traits of Red Sindhi Cows. Livestock Advisor. 19 (12), $1994,10$.

[13]. Joshi, B. K., Singh, A and Mukherjee, S. 2005. Genetic Improvement of Indigenous Cattle for Milk and Drought: A Review. Indian J Anim Sci. 75 (3), 2005, 335-348.

[14]. Joshi, R. K., Chaudhary, R. S and Gahlot, R. S. 1989. A Study of Genetic and Non Genetic Factors in Some Production Traits in Rathi and its Crosses: A Lead Paper and Abstracts National Seminar on Genetics Applied Livestock Production. Veterinary College, 1989, Anand PP:B-11.

[15]. Khadda, B. S., Pathodia, O. P., Taparia, A. L and Choudhary, J. L., Production and Reproduction Performance of Tharparkar Cattle. Indian J. Anim. Sci. 70 (5) , 2012, 1066-1068.

[16]. Kramar, C. Y., Extension of Multiple Range Test to Group Correlated Adjusted Mean. Biometrics. 13:1957, 13-18.

[17]. Kumar, S., Goel, R., Kumar, S. and Singh, P, Economic Traits in Sahiwal Cattle. Indian Vet. J. 89 (6), $2012,43-46$.

[18]. Latpate, N.S, Studies on Factors Affecting Production Efficiency of Red Kandhari Cows and its Crosses, Masteral diss., Marathwada Agricultural University, Parbhani (MS) India,1995.

[19]. Malhotra, P. K and Singh, R. P., Estimation of Lifetime Production in Red Sindhi Cattle Using Ridge Trace Criterion. Indian J. Anim. Sci. 50, 1980, 215-218.

[20]. Monalisa, D., Gandhi, R. S., Raja, T. V., Singh, A. and Sachdeva, G. K. 2010. Influence of Certain Non Genetic Factors on Test Day Milk Records in Sahiwal Cattle. Indian J. Dairy. Sci.63 (6), 2010, 504-506.

[21]. Mruttu, H. A, Studies on Performance of Deoni Cattle at MAU Dairy Farm, Parbhani, doctoral diss., Marathwada Agriculture University, Parbhani (MS),2013.

[22]. Nagadwali, S. B., Kothekar, M. D., Gore, A. K and Deshmukh, S. N, Effect of Non Genetic Factors and Inbreeding on Reproduction and Production Traits in Sahiwal. Indian Vet. J. 73 (2), 1996, 159-163.

[23]. Nanavati, S. and Qureshi, M. I, Study of Peak Yield and Peak Days in Gir Cattle. Indian Vet. J. 73 (4), $1996,762-765$.

[24]. Nanavati, S. and Singh, A, Factors Affecting Reproduction and Production Traits in Nimari Cattle. Indian J. Dairy. Sci. 52 (3), 2009, 207-210.

[25]. Pathak, N. N, Effect of Non Genetic Factors Affecting on Milk Production in Tharparkar and Sahiwal Cattle. BIAF Report on Thermatic Areas and Care Studies, 1980, 61-66.

[26]. Patil, S.V, Genetic Studies on Production and Reproduction Efficiency Traits in Jersey, Sahiwal and Jersey x Sahiwal Crossberd Cows, Masataral diss., MAU, Parbhani.1997

[27]. Raheja, K. L, Note on Days to Attain Peak Yield in Hariana and its Halfbreds. Indian J. Anim. Sci. 52 (7), $1982,565-566$.

[28]. Ramesha, K. P, Khillari Breed of Cattle, Seminar, Workshop and Cattle Show on Indigenous Cattle and Their Role in New Millenium. Erode, Tamil Nadu, India, 2001, 21-22.

[29]. Reddy, K. M and Nagarcenkar, R. 1990. Genetic and Non Genetic Factors Affecting Dry Period in Sahiwal Cows. Livestock Advisor.15, 1990, 33 .

[30]. Salunkhe, M. S, Study on Productive and Reproductive Performance of Deoni Cattle., Masteral diss Marathwada Krishi Vidyapeeth, Parbhani. (MS), 2007.

[31]. SAS (Statistical Analysis System), SAS Version 9.1.3, ASA Institute Inc., Cary, NC, USA, 2002.

[32]. Shelke, B. S., Sakhare, P. G and Deshpande, K. S, Breeding Efficiency and Milk Producing Ability of Red Kandhari and Jersey x Red Kandhari Halfbred Cows. Indian J. Anim. Sci. 62 (1), 1992, 79-80.

[33]. Suryawamshi, S. M., Siddiqui, M. F., Dhumal, M. V., Auradkar, S. K and Borsaikia, A, A Comparative Review on Deoni Cattle Breed of Maharashtra. International Conference on Small Holder Livestock Production System in Developing Country., 2000, 2427.

[34]. Thombre, B. M, Study on Genetic Architecture of few Economic Characters in Holstein Friesian x Deoni Halfbred., doctoral diss., MAU, Parbhani, 1996.

[35]. Thombre, B. M., Mitkari, K. R., Gujar, B. V and Karanjkar, L. M, Factors Affecting Reproductive Traits in Deoni and Holstein Friesian x Deoni Halfbreds. Indian J. Anim. Res. 35 (2), 2001, 131-133.

[36]. Thombre, B. M., Mitkari, K. R and Karanjkar, L. M, Studies on Age at First Calving and Milk Yield in Deoni and Holstein Friesian x Deoni Halfbreds. Indian J. Anim Res. 36 (2), 2002, 141-143.

[37]. Tomar, S. S and Pandey, R. P, Comparative Study of Peak Yield in Tharparkar and its $F_{1}$ Crosses with Exotic Breeds of Cattle. Indian Vet. J. 72(3), 1995, 247-250.

[38]. Umrikar, V. D., Natarjan, N., Thangaraju, P and Rahumathulla, P. S, Factors Influencing Traits of Gir and Jersey x Gir Crossbred Cattle. Cherion. 19 (3), 1990, 131-138.

[39]. Vinoo, R., Rao, N., Gupta, B. R and Rao, B, Study on Productive and Reproductive Traits of Ongole Cattle. Indian J. Anim. Sci. 75 (4), 2005, 438-441.

[40]. Yadav, A. S and Rathi, S. S, Factors Influencing Some Performance Traits in Hariana Cattle. Indian J. Dairy. Sci. 45 (10), 1992, 511-513. 